\title{
Melanoma-Associated Antigen D1
}

National Cancer Institute

\section{Source}

National Cancer Institute. Melanoma-Associated Antigen D1. NCI Thesaurus. Code C26484.

Melanoma-associated antigen D1 (778 aa, $\sim 86 \mathrm{kDa}$ ) is encoded by the human MAGED1 gene. This protein is involved in apoptosis. 